\title{
REVITALISASI PASAR DAN STABILISASI HARGA KOMODITAS PANGAN
}

\section{Market Revitalization and Stabilization of Food Commodity Prices}

\author{
Dwi Ariestiyanti ${ }^{1}$, Vid Adrison ${ }^{2}$ \\ ${ }^{1}$ Pusat Pengkajian Perdagangan Dalam Negeri, Badan Pengkajian \& Pengembangan Perdagangan, \\ Kementerian Perdagangan, JI. M.I Ridwan Rais No.5, Jakarta 10110, DKI Jakarta, Indonesia \\ ${ }^{2}$ Fakuktas Ekonomi dan Bisnis, Universitas Indonesia, Jakarta, 10430, DKI Jakarta, Indonesia \\ Email: dwi.ariestiyanti@yahoo.com
}

Naskah diterima: 18/02/2020; Naskah direvisi: 29/10/2020; Disetujui diterbitkan: 04/11/2020; Dipublikasikan online: 18/12/2020

\begin{abstract}
Abstrak
Penelitian ini bertujuan untuk melihat hubungan antara pelaksanaan program revitalisasi pasar dengan stabilisasi harga komoditas pangan. Penelitian ini dilihat dari sudut pandang pemerintah dan juga menggunakan data pasar dari 95 Kabupten/kota yang ada di Indonesia. Pelaksanaan revitalisasi pasar rakyat berbeda-beda di tiap daerah di Indonesia. Hal ini dilihat dari berapa anggaran yang dikeluarkan di daerah tersebut, kepadatan penduduk, total pasar serta pasar yang direvitalisasi dan juga pendapatan per kapita. Penelitian ini menggunakan data harga 10 komoditas dari Pusat Informasi Harga Pangan Strategis (PIHPS) Nasional, data anggaran revitalisasi pasar yang diperoleh dari Kementerian Perdagangan dan juga data Potensi Desa (PODES) 2014 dan 2018 dari Badan Pusat Statistik (BPS) untuk melihat data jumlah pasar permanen dan semi permanen. Penelitian ini menggunakan metode data panel dari koefisien variasi dan laju perubahan harga dari 10 komoditi pangan per bulan dari tahun 2016-2019 dari 95 kabupaten/kota di Indonesia. Di estimasi dengan model Random Effect. Studi ini membuktikan bahwa pelaksanaan revitalisasi/pembangunan baru pasar rakyat hanya dari sisi anggaran revitalisasi berkorelasi dengan stabilitas harga komoditas pangan. Oleh karena itu, pemberian anggaran untuk revitalisasi pasar harus di awasi karena apabila digunakan secara tepat oleh daerah akan dapat menciptakan stabilisasi harga komoditi di pasar yang sudah direvitalisasi.
\end{abstract}

Kata kunci : Stabilitas Harga, Revitalisasi Pasar, Harga Komoditas Pangan, Random Effect.

\begin{abstract}
This study aims to look at the relationship between the implementation of the market revitalization program and the stabilization of food commodity prices. This research is seen from the perspective of the government and uses market data from 95 districts/cities in Indonesia. The revitalization of people's markets varies in each region in Indonesia. This can be seen from the amount of budget spent in the area, population density, total market and revitalized market and per capita income. This study uses 10 commodity price data from the National Strategic Food Price Information Center (PIHPS), market revitalization budget data obtained from the Ministry of Trade and also 2014 Village Potential Data (PODES) and 2018 from the Central Statistics Agency (BPS) to see market number data permanent and semipermanent. This study uses panel data method from the coefficient of variation and the rate of change in prices of 10 food commodities per month from 2016-2019 from 95 districts / cities in Indonesia. Estimated by the Random Effect model. This study proves that the implementation of revitalization/new development of people's markets only in terms of revitalization budget correlates with the stability of food commodity prices. Therefore, the granting of a budget for market revitalization must be monitored because if it is used properly by the regions, it will be able to create commodity price stabilization in a revitalized market.
\end{abstract}

Keyword: Price Stability, Market Revitalization, Food Commodity Prices, Random Effects

JEL Classification: D40, E63, E64 


\section{PENDAHULUAN}

Harga dan fluktuasi pangan memiliki dampak langsung dan besar pada kesejahteraan rumah tangga terutama di negara-negara berkembang termasuk Indonesia. Hal ini terjadi karena sebagian besar anggaran rumah tangga dihabiskan untuk makanan. Sehingga secara politik maupun ekonomi, fluktuasi harga komoditas pangan penting untuk diteliti (Ceballos, et al, 2017; Nugraheni, 2014)

Fluktuasi harga komoditas pangan sebagian besar diteliti secara makro baik dilihat dari sisi ekspor dan impor, juga banyak dilihat dari pengaruh transmisi harga komoditas pangan dunia terhadap harga komoditas pangan dalam negeri (Hegerty, 2016). Fluktuasi harga pangan dapat disebabkan oleh berbagai hal, antara lain pengaruh dari jumlah stok yang stabil, tidak kekurangan hasil produksi, memaksimalkan fungsi pasar dan biaya transaksi, stabilitas sistem pemerintah (politik) dan juga harga internasional karena dapat memengaruhi harga dalam negeri terutama untuk komoditas pangan impor (Kornher \& Kalkuhl, 2013).

Indonesia sebagai salah satu negara berkembang juga mengalami harga komoditas pangan yang fluktuatif, terutama beras. Hal ini memberikan dampak bagi kesejahteraan masyarakat, terutama masyarakat berpenghasilan rendah karena komoditi beras merupakan makanan pokok utama mereka. (Jensen \& Manrique, 1998; Nugraheni, 2014).

Di Indonesia, fluktuasi dari komoditas pangan dapat disebabkan oleh jumlah penawaran dan permintaan yang terkadang tidak stabil, kegagalan panen karena ketidakpastian cuaca, dan juga terganggunya saluran distribusi antar daerah (Rizaldy, 2017). Selain itu, integrasi antar pasar juga memberikan pengaruh terhadap fluktuasi harga yang terjadi di pasar. Hal ini dikarenakan informasi harga yang tidak sama antar pedagang di pasarpasar tersebut menyebabkan informasi harga yang sampai ke konsumen berbeda-beda (Nuraeni, et al, 2015).

Terjadinya fluktuasi harga komoditas pangan menandakan kurangnya stabilisasi di suatu negara. Dengan adanya kestabilan harga pembangunan ekonomi berjalan lancar dan kondusif untuk mendukung terciptanya stabilitas sosial, politik, dan keamanan. Masyarakat pun juga menginginkan kestabilan harga karena berimplikasi pada risiko dan ketidakpastian yang harus dihadapi 
dalam pengambilan keputusan. Oleh karena itu, stabilisasi harga pangan di Indonesia menjadi hal yang selalu digaungkan pemerintah.

Dilihat dari latar belakang, penyebab dari fluktuasi harga di negara berkembang disebabkan oleh banyak faktor antara lain ketidakseimbangan permintaan dan penawaran, cuaca yang tidak tentu, anomaly produksi, dan lainlain (Irawan, 2016; Rizaldy, 2017). Untuk mengurangi fluktuasi harga pemerintah telah menerapkan berbagai kebijakan yang langsung berhubungan dengan komoditas pangan itu sendiri agar tercipta stabilisasi dan kepastian harga seperti penetapan Harga Eceran Tertinggi untuk komoditi Beras dan Harga Patokan Petani untuk komoditi gula pasir.

Dalam Peraturan Menteri Perdagangan (Permendag) nomor 57/M/DAG/PER/08/2017 tentang penetapan Harga Eceran Tertinggi Beras, Pemerintah telah melakukan beberapa kebijakan untuk menjaga stabilitas dan kepastian harga, serta keterjangkauan harga di beberapa komoditas pangan. Pemerintah menerapkan Harga Eceran Tertinggi yang beras dan juga penetapan harga acuan pembelian di petani serta harga acuan penjualan di konsumen untuk beberapa komoditi pangan lainnya yang tertuang dalam Permendag RI Nomor 96 Tahun 2018.

Pada tahun 2015, pemerintah melakukan upaya pengendalian ketersediaan dan kestabilan harga Barang Kebutuhan Pokok (Pangan) dan Barang Penting secara nasional. Oleh karena itu, baik pemerintah pusat dan daerah, sesuai kewenangannya, memiliki 12 tugas yang harus dilaksanakan dua diantaranya mengembangkan infrastruktur dan sarana perdagangan. Hal ini termasuk program revitalisasi/pembangunan pasar di Indonesia yang tertuang dalam Peraturan Presiden (Perpres) RI nomor 71 tahun 2015 tentang Penetapan dan Penyimpanan Barang Kebutuhan Pokok dan Penting.

Program revitalisasi dan atau pembangunan 5000 pasar rakyat (tradisional) yang tertuang dalam Rencana Pembangunan Jangka Menengah Nasional (RPJMN) tahun anggaran 2015-2019. Mengapa program 5000 Pasar Rakyat? Pasar rakyat merupakan salah satu aspek penting dalam sistem perdagangan nasional karena sebagai tempat bagi petani dan atau nelayan lokal untuk menjual hasil panen atau tangkapannya kepada konsumen. 
Selain itu, dalam Permendag nomor 37/M-DAG/PER/5/2017 menyebutkan bahwa program ini dilakukan juga untuk mengubah sudut pandang masyarakat terhadap pasar rakyat dan merawat eksistensi pasar sehingga memiliki daya saing dan mampu bertahan dalam era persaingan bebas.

Salah satu misi dari revitalisasi/ pembangunan pasar rakyat adalah meningkatkan pendapatan para pedagang pasca revitalisasi dan meningkatkan peran pasar sebagai penyangga ketersediaan barang kebutuhan pokok (Direktorat Jendral Perdagangan Dalam Negeri, Kementerian Perdagangan, 2017). Hal ini sesuai dengan salah satu poin prinsip revitalisasi dari sisi ekonomi, dalam Permendag nomor 37/MDAG/PER/5/2017, adalah peningkatan instrumen stabilisasi harga khususnya terhadap barang kebutuhan pokok.

Dalam Perpres nomor 71 Tahun 2015, terdapat 11 jenis barang yang termasuk ke dalam barang kebutuhan pokok, antara lain beras, kedelai sebagai bahan baku tahu tempe, cabe, bawang merah, gula, minyak goreng, tepung terigu, daging sapi, daging ayam ras, telur ayam ras, dan ikan segar (bandeng, kembung, dan tongkol/tuna/cakalang). Dikatakan sebelumnya bahwa pasar memiliki peran sebagai penyangga ketersediaan barang kebutuhan pokok. Hal ini dapat menjadi barometer stabilisasi harga pangan di tingkat nasional.

Pelaksanaan revitalisasi pasar rakyat ini masih berjalan pelaksanaannya. Telah terdapat beberapa penelitian mengenai revitalisasi pasar rakyat ini tetapi dengan cakupan yang kecil, seperti dalam wilayah tertentu dan juga hanya membandingkan pasar satu dengan pasar yang lainnya, harga jual barang setelah revitalisasi dan juga lebih memfokuskan kepada penelitian mengenai kenaikan pendapatan para pedagang pasar. Hingga saat ini belum ditemukan penelitian yang menghubungkan revitalisasi/ pembangunan pasar rakyat dengan stabilisasi harga komoditi barang kebutuhan pokok.

Salah satu penelitian mengenai revitalisasi pasar yaitu mengenai dampak dari revitalisasi pasar yang mengakibatkan kenaikan harga komoditi yang dijual di Pasar BSD (Ranjani, Ayu S, \& Nurhikmah, 2018). Namun hal tersebut berbanding terbalik dengan yang terjadi di Pasar Sei Sikambing Medan, Sumatera Utara, harga yang ditawarkan di pasar tersebut 
masih terjangkau sesuai dengan kebutuhan konsumen walaupun telah dilakukan revitalisasi pasar (Sihombing, Dewi, \& Astika, 2019). Program revitalisasi ini juga dilakukan di Pasar Adat Intaran Sanur. Setelah direvitalisasi di Pasar tersebut konsumen tidak mengeluhkan tingkat harga jual barang-barang yang ada di pasar tersebut (Arimbawa \& Marhaeni, 2017).

Revitalisasi pasar yang terjadi di beberapa pasar di Kampung Lalang Medan memberikan dampak yang positif bagi konsumen dan pedagang. Dari beberapa indikator, kesegaran bahan kebutuhan pokok yang dijual dan juga harga yang masih dapat di tawar serta masih dibawah harga di retail modern menjadi pendorong konsumen untuk tetap berbelanja di pasar-pasar tersebut (Sihombing, et al, 2019).

Selain itu, alokasi pendanaan dalam pelaksanaan revitalisasi pasar di Pasar Bulu Kota Semarang ternyata tidak dilakukan secara tepat karena fasilitas yang seharusnya terbangun dengan pelaksanaan revitalisasi ini tidak ada di pasar tersebut (Nurlaela \& Hariani, 2017). Terdapat juga perbedaan antara pasar tradisional zaman dahulu dan sekarang mulai dari segi jenis dagangan, peran pasar, bentuk interaksi, dan sistem rotasi pasar. Dampak yang ditimbulkan oleh revitalisasi yaitu dari segi bangunan menjadi lebih bagus, lebih bersih, tidak becek lagi jika hujan, tetapi dari segi pendapatan, tidak semua pasar mengalami peningkatan setelah direvitalisasi (Ismayati, 2017).

Untuk meciptakan stabilisasi harga yang dilihat dari sisi sarana perdagangan masih belum banyak dilakukan. Pasar Rakyat merupakan salah satu sarana perdagangan. Revitalisasi/pembangunan pasar rakyat dikatakan sebagai instrumen revitalisasi ekonomi untuk stabilisasi harga komoditas pangan. Oleh karena itu, penelitian dilakukan untuk mengetahui hubungan dari revitalisasi/ pembangunan pasar dengan stabilisasi dan perubahan harga komoditas pangan di Indonesia. Stabilisasi harga direpresentasi dengan menggunakan laju perubahan harga dan juga koefisien variasi.

\section{Kebijakan Revitalisasi Pasar}

Rancangan awal RPJMN 20152019, pengembangan kapasitas perdagangan nasional dapat dilakukan dengan melalui dua arah yaitu dari sisi perdagangan dalam negeri dan luar negeri. Pengembangan kapasitas perdagangan dalam negeri tahun 2015- 
2019 memiliki lima target, antara lain turunnya rata-rata biaya logistik terhadapa PDB sebesar $5 \%$ setiap tahunnya, menurunnya waktu dwelling time hingga 3-4 hari di tahun 2019, PBD riil subkategori perdagangan besar dan eceran meningkat, koefisien variasi harga kebutuhan pokok antarwaktu berada di bawah $9 \%$ dan dibawah $14,2 \%$ untuk antarwilayah, serta revitalisasi/pembangunan 5000 pasar rakyat selama lima tahun.

Dapat dilihat bahwa program revitalisasi/pembangunan pasar rakyat masuk ke dalam target kebijakan pengembangan kapasitas perdagangan dalam negeri di RPJMN Tahun 20152019. Pasar rakyat sebagai salah satu sarana perdagangan perlu ditingkatkan ketersediaan, kelayakan, dan kualitasnya (nyaman, bersih dan sehat) untuk memperlancar arus distribusi barang kebutuhan pokok, terutama untuk daerah-daerah yang masih sedikit memiliki sarana perdagangan.

Mengembangkan infrastruktur dan sarana perdagangan dapat diartikan sebagai melakukan revitalisasi dari pasar rakyat seperti yang tertuang dalam RPJMN 2015-2019. Oleh karena itu pemerintah pusat dan daerah memiliki tugas untuk mengembangkan infrastruktur dan sarana perdagangan dengan tujuan mengendalikan ketersediaan dan kestabilan harga barang kebutuhan pokok (Pangan) dan barang penting di Indonesia.

Dalam Permendag nomor 37/MDag/Per/5/2017, yang dimaksud sarana perdagangan antara lain pasar rakyat, gudang yang tidak bersistem resi gudang, dan pusat distribusi yang bertujuan untuk mendukung kelancaran arus distribusi barang. Selain itu, yang dimaksud pembangunan/revitalisasi dari sarana perdagangan yaitu berusaha meningkatkan atau memberdayakan sarana dan prasarana fisik, manajemen, sosial budaya, dan ekonomi dari sarana perdagangan.

Untuk pembiayaan atau anggaran program revitalisasi/ pembangunan baru pasar rakyat dapat bersumber dari Anggaran Pendapatan dan Belanjan Negara (APBN) melalui Dana Tugas Pembantuan dan Dana Alokasi Khusus. Dana Tugas Pembantuan (TP) merupakan dana yang berasal dari APBN yang dilaksanakan oleh daerah dan desa yang mencakup semua penerimaan dan pengeluaran dalam rangka pelaksanaan tugas pembantuan. Dana Alokasi Khusus (DAK) merupakan dana yang berasal dari APBN yang dialokasikan kepada daerah tertentu dengan tujuan untuk 
membantu mendanai kegiatan khusus yang menjadi urusan daerah sesuai dengan prioritas nasional.

Revitalisasi pasar rakyat dilakukan melalui 4 (empat) prinsip yaitu revitalisasi fisik, manajemen, ekonomi, dan sosial. Dengan kata lain, melakukan perbaikan dan peningkatan kualitas, kondisi fisik pasar serta sistem manajemen pengelolaan pasar yang jelas. Revitalisasi pasar dapat menciptakan lingkungan yang menarik sehingga memberikan dampak positif bagi kehidupan sosial masyarakat. Pada akhirnya dapat mengakomodasi kegiatan ekonomi informal dan formal (local economic development) dan juga sebagai instrumen peningkatan stabilitas harga kebutuhan bahan pangan pokok.

Revitalisasi pasar rakyat dilakukan untuk meningkatkan daya saing dan omset para pedagang sehingga tingkat kesejahteraan bertambah, memperlancar arus distribusi dan logistik bahan kebutuhan, serta menguatkan pasar dalam negeri di era perdagangan global saat ini. Terdapat beberapa kriteria pemilihan lokasi prioritas revitalisasi atau pembangunan pasar rakyat yaitu pasar yang telah berusia lebih dari 25 tahun, mengalami kebakaran, pasca bencana alam dan konflik sosial, pasar di daerah tertinggal atau daerah yang kurang memiliki sarana perdagangan, terakhir daerah yang memiliki potensi perdagangan besar. Tujuan dari revitalisasi pasar meningkatkan pendapatan tidak hanya pedagang tetapi juga pelaku-pelaku ekonomi di sekitarnya. Selain itu juga mempermudah transaksi jual beli.

\section{METODE}

Penelitian ini menggunakan data panel dari data Pusat Informasi Harga Pangan Strategis (PIHPS) Nasional Bank Indonesia (BI) Tahun 2016-2019, Badan Pusat Statistik (BPS), Kementerian Perdagangan, dan juga Kementerian Pertanian. PIHPS melakukan survei terhadap 10 komoditas pangan (Beras, Bawang Merah, Bawang Putih, Cabai Merah, Cabai Rawit, Daging Sapi, Daging Ayam Ras, Telur Ayam Ras, Gula Pasir, dan Minyak Goreng).

Data PIHPS terpilih sebagai sampel karena memuat data harga ratarata per bulan dari 10 komoditas di 95 kabupaten/kota yang berasal dari seluruh pasar yang disurvei BI. Data harga yang disurvei adalah harga eceran hasil transaksi yang terjadi antara penjual (pedagang eceran) dan pembeli (konsumen) dalam satuan standar harga yang telah ditetapkan BI. 
Data BPS digunakan untuk melihat data kepadatan penduduk dari 95 kabupaten/kota dan juga data Pendapatan Domestik Regional Bruto (PDRB) per kapita dari setiap kabupaten/kota. Data kepadatan penduduk digunakan sebagai pembagi dari dana anggaran pasar yang diperoleh dari kabupaten/kota. Selain data kepadatan penduduk dan PDRB per kapita, penelitian juga menggunakan data Potensi Desa (PODES) tahun 2014 dan 2018 dari BPS. Data PODES digunakan untuk melihat jumlah pasar permanen dan semi permanen di setiap kabupaten/kota. Jumlah pasar permanen dan semi permanen akan menjadi pembagi dalam variabel rasio pasar.

Untuk data Kementerian Perdagangan memuat data anggaran pasar untuk program revitalisasi dan atau pembangunan baru pasar rakyat tersebut. Data yang diperoleh dari tahun 2015-2018 di seluruh kabupaten kota. Data anggaran ini, nantinya akan di mundurkan satu tahun dengan asumsi bahwa revitalisasi /pembangunan baru membutuhkan waktu kurang lebih satu tahun dari tahun pertama program ini dijalankan. Selain data anggaran, penelitian ini juga menggunakan jumlah pasar yang direvitalisasi di kabupaten/kota. Data ini akan menjadi pembentuk dari variabel rasio pasar. Selanjutnya data Kementerian Pertanian digunakan untuk melihat daerah penghasil komoditas hortikultur dan beras. Data tersebut yang menjadi dasar dari penentuan dummy hortikultur.

Penelitian ini menggunakan variabel koefisien variasi dan laju perubahan harga. Koefisien variasi (simpangan terhadap rata-rata) dari masing-masing komoditas dihitung berdasarkan data harga secara runtun waktu menggambarkan fluktuasi digunakan untuk mengetahui stabilitas harga suatu komoditas. Semakin kecil nilai koefisien variasi (CV) dapat diinterpretasikan bahwa harga relatif stabil atau memiliki fluktuasi yang rendah, begitu pula sebaliknya. Koefisien variasi diperoleh dari standar deviasi suatu variabel dibagi dengan rata-ratanya, dapat dirumuskan sebagai berikut:

$$
C V=\frac{\text { Standard Deviasi }}{\text { Rata-rata }}=\frac{\sqrt{\frac{\sum_{i=1}^{n}(P-\bar{P})}{n}}}{\bar{P}}
$$

Perubahan harga (Growth) dihitung untuk melihat laju perubahan harga yang terjadi pada masing-masing komoditas yang menjadi objek penelitian. Laju perubahan harga yang 
terjadi setiap bulannya di rata-ratakan menjadi satu tahun untuk melihat laju perubahan harga per tahun. Hal ini berkaitan dengan pemberian anggaran program revitalisasi pasar yang dilakukan per tahun. Perhitungan laju perubahan harga diperoleh dari pengurangan harga pada bulan berjalan dikurangin dengan bulan sebelumnya dibagi dengan harga pada bulan sebelumnya, dapat dirumuskan sebagai berikut:

$$
\text { Growth }=\frac{\operatorname{Harga}_{t}-\operatorname{Harga}_{(t-1)}}{\operatorname{Harga}_{(t-1)}} \times 100 \%
$$

Penelitian menggunakan data panel dengan model random effect. Penggunaan model random effect dikarenakan adanya penggunaan variabel kontrol dummy untuk merepresentasikan ketidaktahuan tentang model yang sebenarnya yang tidak dapat dilakukan dengan model fixed effect (Gujarati \& Porter, 2009).

Selain itu, model random effect mengasumsikan bahwa efek individu tidak berkorelasi dengan regresor manapun maka estimasi varians error dispesifikan untuk kelompok atau waktu. Oleh karena itu, $\varepsilon_{\text {it }}$ adalah komponen komposit error. Inilah mengapa model random effect disebut sebagai Error Component Model. Baik intercept maupun slope sama antar individu. Perbedaan diantara individu atau periode waktu terletak dalan error spesifik individu bukan pada intersepnya (Susanti, 2013).

CVKomoditi $_{\mathrm{it}}=\beta_{0}+\beta_{1}$ AnggaranDens $_{\mathrm{it}}+\beta_{2}$ RasioPasar $_{\mathrm{it}}+\beta_{3}$ PDRBKap $_{\mathrm{it}}+\beta_{4}$ dRevitalisasi $_{\mathrm{it}}+\beta_{5}$ dKota $_{\mathrm{it}}+$

$$
\beta_{6} d \text { Horti }_{\mathrm{it}}+\beta_{7} d \text { Pulau }_{\mathrm{it}}+\varepsilon_{\mathrm{it}}
$$

dan

HKomoditi $_{\mathrm{it}}=\beta_{0}+\beta_{1}$ AnggaranDens $_{\mathrm{it}}+\beta_{2}$ RasioPasar $_{\mathrm{it}}+\beta_{3}$ PDRBKap $_{\mathrm{it}}+\beta_{4}$ dRevitalisasi $_{\mathrm{it}}+\beta_{5}$ dKota $_{\mathrm{it}}+$

$$
\beta_{6} d \text { Horti }_{\mathrm{it}}+\beta_{7} d \text { Pulau }_{\mathrm{it}}+\varepsilon_{\mathrm{it}}
$$

Dimana CVKomoditi it adalah Koefisien Variasi Harga dari masing-masing komoditas; HKomoditilit adalah laju perubahan harga dari masing-masing komoditas; AnggaranDensity adalah Variabel anggaran pasar revitalisasi dibagi dengan kepadatan penduduk di masing-masing kabupaten/kota; Rasio Pasar adalah variabel rasio pasar dari total pasar yang direvitalisasi dibagi dengan total pasar yang ada di tiap Kabupaten/Kota; PDRBCap adalah variabel nilai PDRB per kapita dari setiap kabupaten/kota; dRevitalisasi 
adalah variabel dummy untuk adanya pelaksanaan revitalisasi pada tahun $\mathrm{t}$ (1 = ada); dKota adalah variabel dummy untuk kabupaten/kota, $(1=$ Kota $)$; dHortikultur adalah variabel dummy untuk kabupaten/kota penghasil tanaman hortikultur (1 = penghasil hortikultur); dPulau adalah variabel dummy untuk kabupaten/kota yang berada di pulau jawa $(1=$ berada di pulau jawa); $\varepsilon$ adalaherror term; i adalah data kabupaten/kota $(1,2, \ldots, 95)$; dan $t$ adalah unit waktu 2016-2019.

Penelitian menggunakan satu variabel penjelas utama yaitu anggaran revitalisasi. Data anggaran revitalisasi direpresentasikan dengan nilai anggaran yang diperoleh untuk melakukan revitalisasi/pembangunan baru per kabupaten/kota. Dalam hal ini data anggaran yang diperoleh akan di bagi dengan data kepadatan penduduk di setiap kabupaten/kota yang di observasi. Hal ini dikarenakan dalam Permendag Nomor 56/M-DAG/PER/9/2014 disebutkan bahwa jumlah pembangunan pasar tradisional di suatu daerah perlu melihat kepadatan penduduk. Oleh karena adanya perbedaan tahun antara data harga dari PIHPS dengan data pasar dari Kementerian Perdagangan, maka data anggaran revitalisasi dimundurkan satu tahun menjadi tahun 2016-2019 dengan asumsi tidak ada informasi mengenai kapan pasar tersebut selesai dilakukan revitalisasi/pembangunan baru sehingga dapat digunakan kembali.

Selain variabel penjelas utama, penelitian juga menggunakan beberapa variabel kontrol berupa karakteristik dari kabupaten/kota, pasar, dan juga hal yang memengaruhi perubahan harga. Variabel kontrol yang digunakan antara lain, rasio pasar, Pendapatan Domestik Regional Bruto (PDRB) per kapita di tiap kabupaten/kota, jenis kabupaten/kota, penghasil komoditas, dan lokasi pasar.

Variabel kontrol pertama yaitu rasio pasar. Rasio ini berasal dari jumlah pasar yang di revitalisasi dengan jumlah pasar (total dari pasar permanen dan semi permanen) yang ada di 95 kabupaten/kota. Rasio ini digunakan untuk melihat perbandingan jumlah pasar yang direvitalisasi dengan total jumlah pasar yang ada di kabupaten/kota itu. Pasar permanen dan semi permanen digabungkan karena pada pasar yang di revitalisasi tidak dijelaskan apakah pasar yang di revitalisasi merupakan pasar semi permanen atau permanen. Walaupun dalam Permendag Nomor 37/M-DAG/PER/5/2017 tentang 
Pedoman Pembangunan dan

Pengelolaan Sarana Perdagangan

disebutkan bahwa pasar semi

permanen yang menjadi embrio dalam

program revitalisasi. Namun

berdasarkan hasil wawancara dengan

Kepala Subdirektorat Pengembangan

Sarana Distribusi, Direktorat Sarana

Distribusi Logistik, Direktorat Jendral

Perdagangan Dalam Negeri,

Kementerian Perdagangan dalam

pelaksanaannya terdapat pula pasar

yang sudah berupa pasar permanen yang direvitalisasi.

Variabel kontrol kedua yaitu Pendapatan Domestik Regional Bruto (PDRB) per kapita. Semakin besar nilai PDRB per kapita di suatu kabupaten/kota maka tingkat kesejahteraan masyarakat di kabupaten/kota tersebut semakin tinggi. Variabel kontrol ketiga adalah dummy revitalisasi. Pelaksanaan revitalisasi tidak dilaksanakan secara serentak di 95 kabupaten/kota sampel penelitian. Pelaksanaan revitalisasi/pembangunan baru pasar rakyat tersebut dilihat dari kesiapan pemerintah daerah dalam memenuhi data-data yang diminta oleh pemerintah pusat untuk pelaksanaan revitalisasi/pembangunan baru pasar rakyat tersebut.
Variabel kontrol selanjutnya adalah dummy jenis kota yang dikelompokkan menjadi kabupaten dan kota. Jenis kota menggambarkan perbedaan yang dimiliki dari kabupaten dan kota terutama perbedaan dalam hal perekonomian, kependudukan dan sosial budaya yang dilihat berdasarkan Peraturan Pemerintah (PP) No. 38/2007 tentang pembagian urusan Pemerintahan.

Variabel kontrol selanjutnya adalah dummy penghasil komoditas yang dikelompokkan menjadi daerah penghasil beras-hortikultura dan bukan keduanya. Tanaman hortikultur yang dimaksud adalah tanaman sayuran semusim yang berumur kurang dari satu tahun dan tidak dibedakan lahan dan daerah tanamnya. Asumsi penggunaan dummy penghasil hortikultur yaitu di Indonesia harga untuk komoditas hortikultur dan beras lebih berfluktuasi dibandingkan dengan komoditas lainnya. Oleh karena itu, untuk daerah penghasil beras dan hortikultur seharusnya tidak mengalami fluktuasi harga yang lebih tinggi jika dibandingkan dengan daerah lainnya apabila sedang mengalami anomaly produksi (Irawan, 2016). 
Variabel kontrol yang terakhir adalah dummy lokasi pasar yang menggambarkan apakah kabupaten/ kota sebagai lokasi pasar dibangun/direvitalisasi berada di pulau jawa atau tidak. Hal ini untuk melihat jalur distribusi dari komoditas yang ada. Semakin Panjang jalur distribusi komoditas, terutama komoditas impor, maka akan memengaruhi fluktuasi harga komoditas di pasar (Kornher \& Kalkuhl, 2013). Selain itu juga, apabila terjadi kondisi gagal panen dari komoditas yang sebagian besar diproduksi dipulau jawa akan memengaruhi stok dan fluktuasi harga di pasar.

\section{HASIL DAN PEMBAHASAN}

\section{Analisis Deskriptif}

Pasar dapat dikatakan menjadi tempat yang dapat memengaruhi fluktuasi harga komoditas karena apabila di suatu daerah hanya memiliki jumlah pasar yang sedikit kemungkinan jumlah pedagangnya juga sedikit. Oleh karena sedikitnya jumlah pedagang, maka akan dapat memengaruhi harga jual ke konsumen. Pasar yang jumlah pedagangnya sedikit berbeda dengan pasar di daerah lain yang jumlah pasar dan pedagannya lebih banyak (Crucini et al., 2010; Irawan, 2016; Sharp \& Uebele, 2013).
Homogenitas dan melimpahnya komoditas pertanian yang akan dijual membuat petani tidak mempunyai bargaining position untuk memengaruhi harga dan menerima hanya sebagai price taker. Sebaliknya untuk tingkat pedagang pengumpul atau tengkulak yang jumlahnya relatif sedikit cenderung membentuk pasar oligopoli sehingga mempunyai kekuatan untuk memengaruhi harga. Seringkali para pedagang pengumpul/tengkulak tersebut membentuk sebuah kartel yang dapat membuat kesepakatan dan membentuk harga pasar (Pindyck \& Rubinfeld, 2013). Oleh karena itu, penelitian ini memilih revitalisasi pasar dihubungkan dengan fluktuasi harga yang diintepretasikan dari koefisien variasi dan laju perubahan harga.

Program revitalisasi atau pembangunan baru pasar di mulai pada tahun 2015, dengan asumsi proses revitalisasi/pembangunan baru selesai dan dapat digunakan kembali tahun berikutnya. Salah satu tujuan program ini adalah untuk mewujudkan stabilisasi harga komoditas pangan, dapat dilihat dari koefisien variasi harga komoditas. Nilai koefisien variasi ini diperoleh dari total standar deviasi dibagi dengan total rata-rata harga per bulan setiap tahunnya dari tahun 2016-2019. 

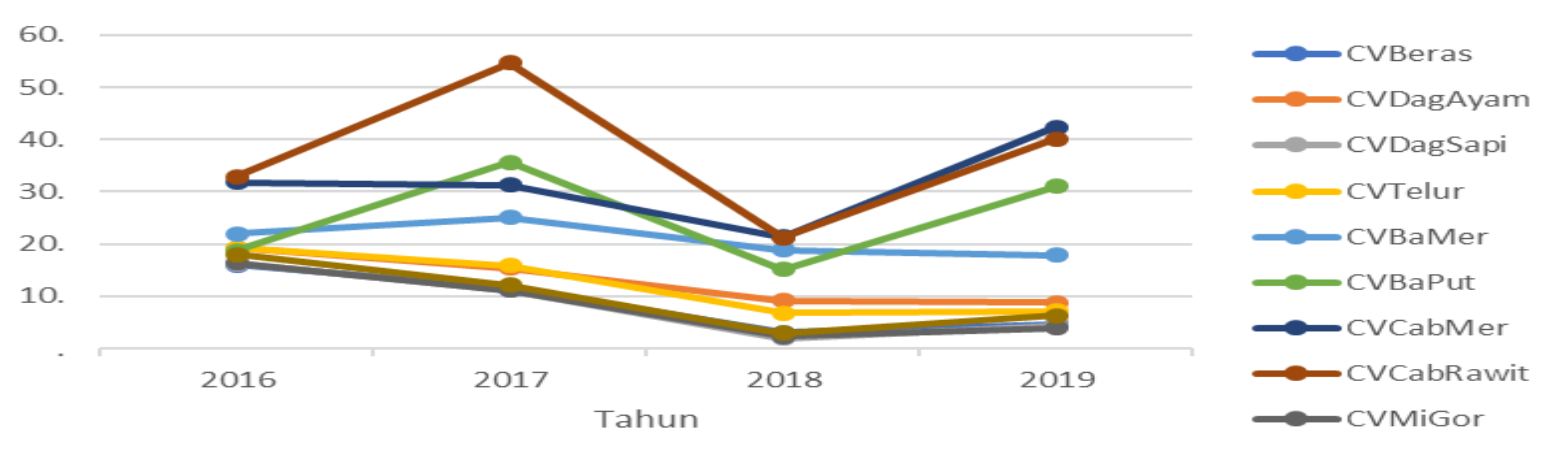

\section{Gambar 1. Koefisien Variasi Harga Komoditas Harga Pangan, 2016-2019}

Sumber: Pusat Informasi Harga Pangan Strategis Nasional (2019), diolah

Pada Gambar 1 terlihat nilai koefisien variasi 10 komoditas pangan dari 95 kabupaten/kota. Terlihat bahwa nilai koefisien variasi dari cabai rawit dan bawang putih yang mengalami gejolak harga yang cukup signifikan bila dibandingkan ketujuh komoditi yang lainnya. Apabila melihat perubahan harga dari tahun 2016 ke tahun 2017, koefisien variasi harga untuk tiga komoditas pangan yang mengalami kenaikan yaitu bawang merah, bawang putih dan cabai rawit. Namun hanya cabai rawit mengalami lonjakan harga yang cukup signifikan, dikarenakan adanya kenaikan harga yang cukup signifikan pada awal tahun 2017 yang disebabkan adanya kelangkaan pasokan di awal tahun.

Selain menggunakan koefisien variasi harga, stabilisasi harga dapat dilihat menggunakan laju perubahan harga. Nilai laju perubahan harga diperoleh dari pengurangan harga pada bulan berjalan dengan harga pada bulan sebelumnya dibagi dengan harga pada bulan sebelumnya. Hasil dari perhitungan tersebut dirata-ratakan menjadi tahunan dan dipersentasekan. Gambar 2. merupakan rata-rata laju perubahan per tahun dari 95 kabupaten/kota. 


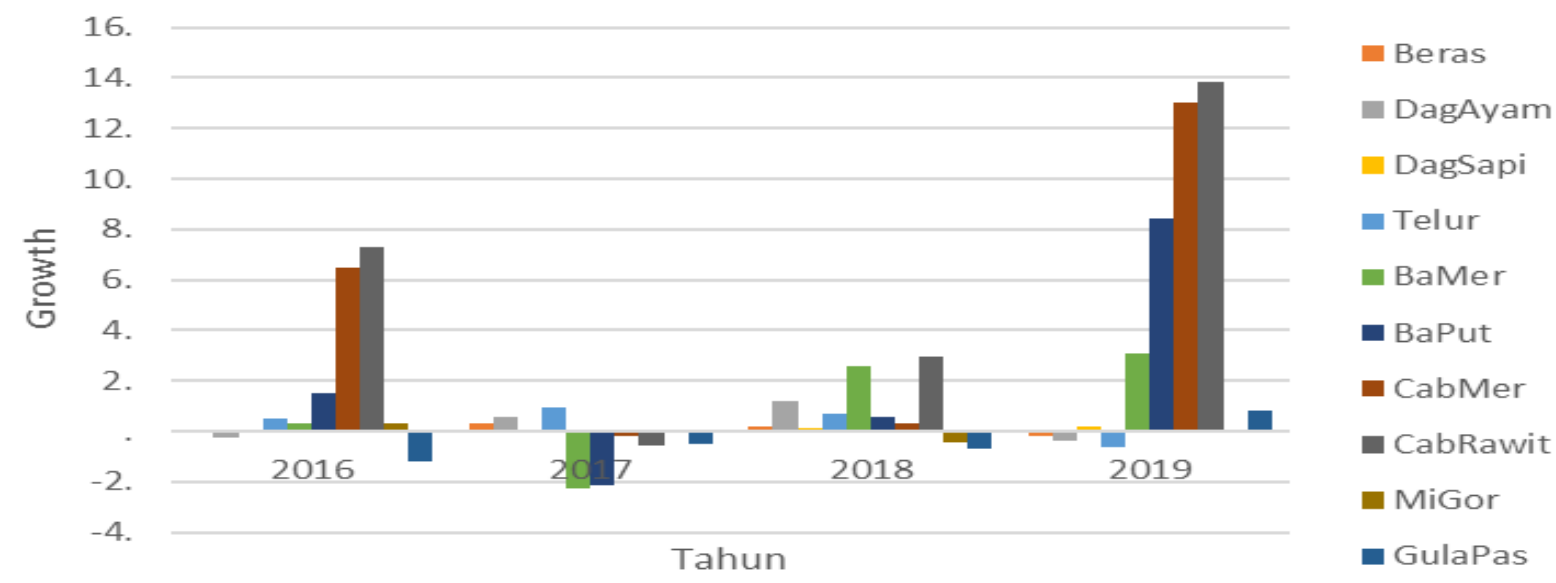

\section{Gambar 2. Laju Perubahan Harga Komoditas Pangan}

Sumber: Pusat Informasi Harga Pangan Strategis Nasional (2019), diolah

Pada Gambar 2. dapat dilihat ratarata laju perubahan harga 10 komoditas pangan dari 95 kabupaten/kota setiap tahunnya. Dapat dilihat bahwa pada tahun 2016 dan tahun 2019 dari 10 komoditas yang diteliti, hanya terdapat tiga komoditas yang mengalami tren kenaikan harga antara lain bawang putih, cabai merah, cabai rawit. Pada tahun 2019, rata-rata laju perubahan harga untuk komoditi bawang putih sebesar $8,43 \%$, untuk komoditi cabai merah $13 \%$, dan $13,85 \%$ untuk komoditi cabai rawit.

Dengan melihat laju perubahan harga pada komoditas cabai rawit dan cabai merah, selama tahun 2019 kedua komoditas tersebut sering mengalami gagal panen di daerah penghasilnya. Akibat kegagalan panen tersebut maka harga jual di pasar menjadi sangat berfluktuatif. Hal ini menjadikan kedua komoditas tersebut memberikan andil terhadap inflasi yang terjadi pada tahun 2019 (Media Indonesia, 2019).

\section{Hasil Estimasi}

Berdasarkan hasil estimasi pada Tabel 1., variabel anggaran per kepadatan (density) menunjukkan korelasi negatif dengan koefisien variasi pada tingkat signifikansi pada $\alpha<1 \%$, kecuali untuk komoditas bawang merah dan cabai merah tingkat signifikansi $\alpha<$ $5 \%$. Setiap kenaikan anggaran per kepadatan mulai dari Rp 301,- hingga Rp 531,- akan menurunkan nilai koefisien variasi harga dari masingmasing komoditas pangan. Komoditas daging ayam ras, daging sapi, telur, bawang merah, bawang putih, cabai merah, cabai rawit dan gula pasir juga menunjukkan tingkat signifikansi $\alpha<1 \%$ 
dan $\alpha<5 \%$ pada variabel anggaran per kepadatan (density).

Hal ini menunjukkan bahwa pemberian anggaran untuk revitalisasi/ pembangunan baru pasar rakyat yang sesuai tingkat kepadatan penduduk akan dapat menurunkan fluktuasi harga yang dilihat dari koefisien variasi harga tersebut. hal ini dikarenakan jumlah pembangunan pasar tradisional di suatu daerah perlu melihat kepadatan penduduk. Apabila pasar yang direvitalisasi menjadi lebih besar sesuai dengan jumlah kepadatan penduduk tersebut kemungkinan besar akan semakin banyak masyarakat yang berbelanja di pasar yang telah direvitalisasi tersebut.

Untuk variabel dummy jenis kota, menunjukkan bahwa ada bedanya stabilisasi harga di pasar yang terletak di kabupaten dengan yang di kota. Untuk variabel dummy hortikultur pun menunjukkan bahwa hanya komoditi cabe rawit yang menunjukkan ada bedanya stabiliasi harga bila daerah sekitar pasar tersebut penghasil holtikultur dan bila terjadi anomali produksi.

Untuk rasio pasar, PDRB per kapita, pelaksanaan revitalisasi, dan lokasi pasar di luar pulau jawa tidak menunjukkan adanya perbedaan untuk penelitian mengenai stabilisasi harga komoditi berkorelasi revitalisasi pasar. Pada rasio pasar, jumlah pasar yang direvitalisasi masih lebih sedikit jika dibandingkan dengan jumlah pasar yang ada. Oleh karena itu, jumlah pasar yang direvitalisasi tidak terlalu terlihat pengaruhnya.

Pelaksanaan revitalisasi pasar baru dapat dirasakan adanya perbedaan terhadap stabilisasi harga pada tahun 2018 dan 2019 atau tiga tahun setelah program revitalisasi berjalan. Pelaksanaan revitalisasi berkorelasi dengan stabilisasi harga pada komoditas-komoditas tersebut.

Laju perubahan harga yang terjadi di masing-masing komoditas menunjukkan tingkat inflasi di tingkat komoditas tersebut. Berdasar Tabel 2. mengenai korelasi laju perubahan harga dan revitalisasi pasar hanya variabel anggaran per kepadatan (density) yang menunjukkan tingkat signifikansi pada $\alpha$ $<1 \%$ dan $\alpha<5 \%$. Hasil estimasi menunjukkan korelasi dari perubahan harga dengan revitalisasi pasar dibedakan menjadi korelasi positif dan negatif.

Untuk komoditas beras, bawang putih, dan cabai merah menunjukkan korelasi positif antara laju perubahan harga dengan revitalisasi pasar. 
Pelaksanaan revitalisasi pasar dapat meningkatkan laju perubahan harga dari ketiga komoditas tersebut. Untuk daging ayam, daging sapi, telur dan cabai rawit menunjukkan korelasi negatif antara laju perubahan harga dengan revitalisasi pasar. Pelaksanaan revitalisasi pasar dapat mengurangi laju perubahan harga dari keempat komoditas tersebut. Sedangkan untuk tiga komoditi lainnya tidak menunjukkan korelasi dari laju perubahan harga yang terjadi dari pelaksanaan revitalisasi pasar ini.

Pada tahun pelaksanaan revitalisasi dan lokasi pasar yang berada di kota/kabupaten menunjukkan adanya perbedaan pada komoditi gula pasir saja. Untuk pasar yang terletak di daerah penghasil hortikultur yang menunjukan adanya perbedaan pada komoditi bawang merah dan cabe rawit. Begitu juga dengan pasar yang terletak diluar pulau jawa, menunjukkan adanya perbedaan bagi komoditi telur dan cabai rawit. Perbedaan tersebut dilihat dari pelaksanaan revitalisasi jika dikorelasikan dengan laju perubahan harga.

Sama halnya dengan hasil estimasi koefisien variasi, pada estimasi laju perubahan harga ini pun terdapat beberapa variabel yang tidak menunjukkan perbedaan pelaksanaan revitalisasi pasar. Pada Tabel 2 hanya rasio pasar dan PDRB per kapita yang tidak menunjukkan adanya perbedaan untuk penelitian mengenai stabilisasi harga komoditi berkorelasi revitalisasi pasar. Pada estimasi laju perubahan harga berkorelasi dengan revitalisasi pasar ini, juga baru dapat dirasakan adanya perbedaan dari pelaksanaan revitalisasi pasar terhadap stabilisasi harga pada tahun 2018 dan 2019 atau tiga tahun setelah program revitalisasi berjalan.

Tabel 1 dan Tabel 2, keduanya menunjukkan variabel anggaran per kepadatan (density) yang berdampak signifikan. Oleh karena itu, pemberian anggaran dari pemerintah untuk pelaksanaan revitalisasi pasar memiliki andil yang cukup penting bagi pasar tersebut dimana pada akhirnya juga akan berkorelasi dengan stabilitas harga komoditi bahan kebutuhan pangan pokok.

Namun, apabila melihat kembali kepada penelitian terdahulu, yang memberikan hasil bahwa konsumen tidak terlalu khawatir dengan tingkat harga yang ditawarkan di pasar setelah direvitalisasi dapat dikatakan sejalan dengan penelitian. Hal ini dikarenakan jika harga komoditi kebutuhan pokok yang mengalami fluktuasi harga seperti pada hasil estimasi, konsumen atau masyarakat akan tetap membelinya. 


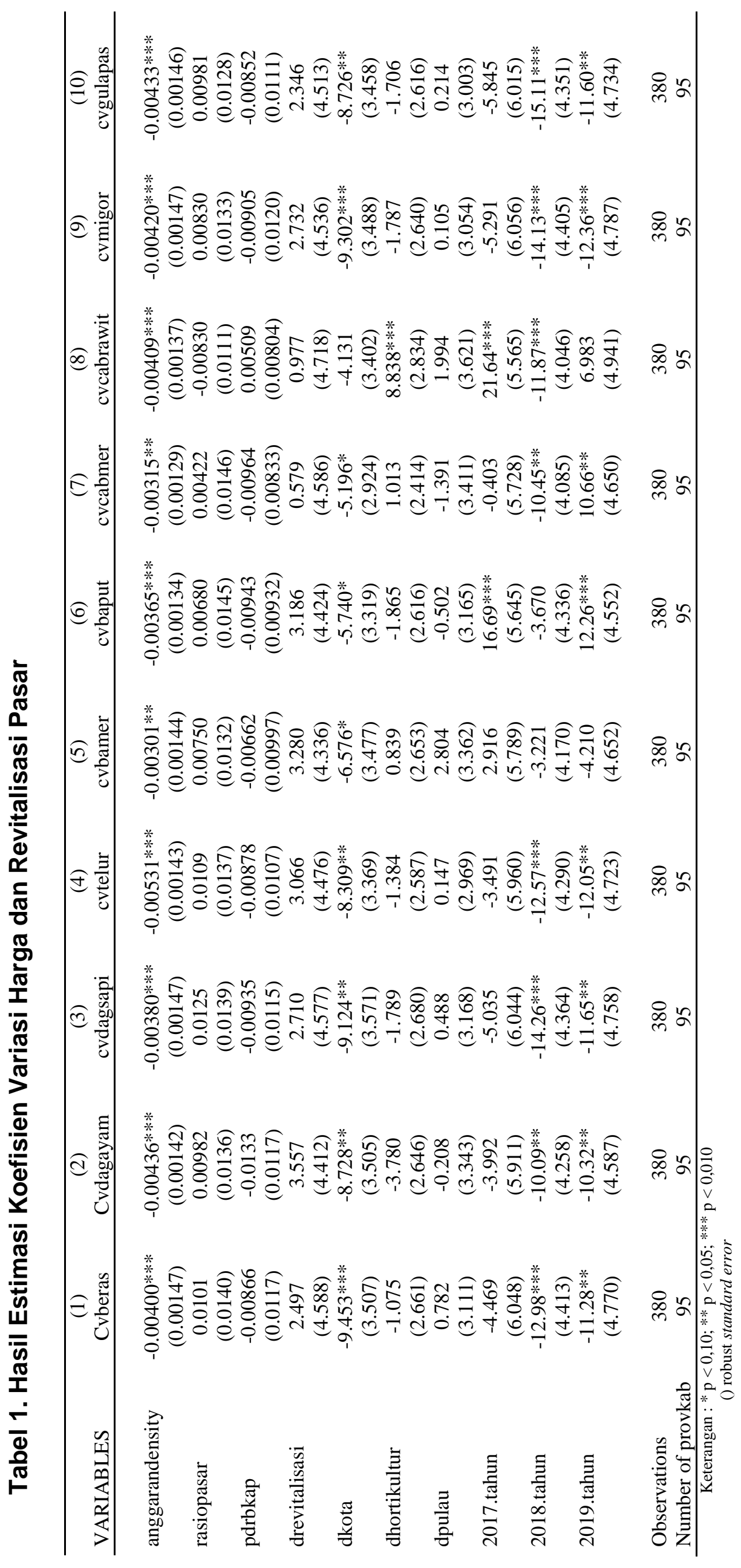




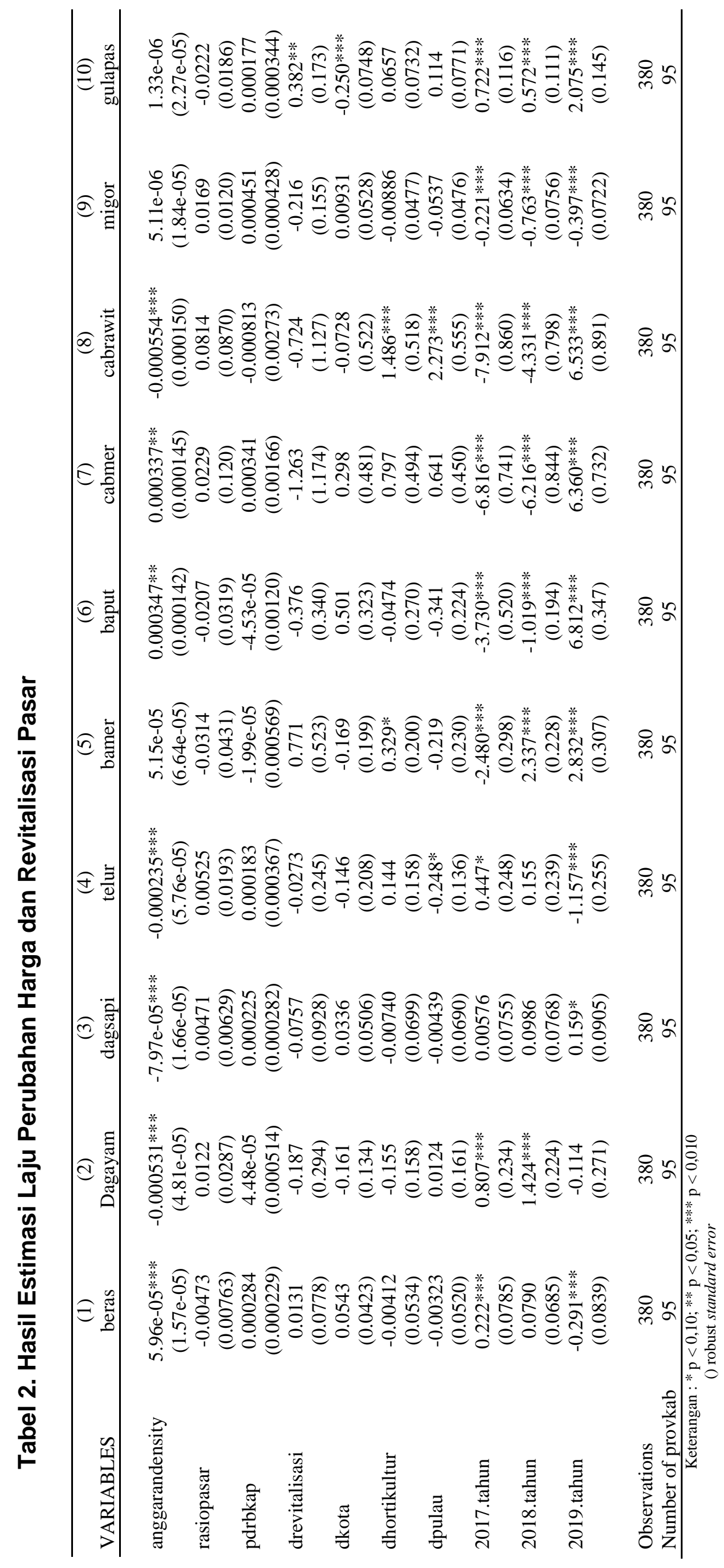


KESIMPULAN DAN REKOMENDASI KEBIJAKAN

Hasil estimasi dengan menggunakan variabel dependen koefisien variasi harga. Program revitalisasi pasar di representasikan dengan variabel anggaran per kepadatan. Pada hasil estimasi pada kosefisien variasi, menunjukkan korelasi antara revitalisasi/ pembangunan pasar dengan koefisien variasi. Hal ini dapat diartikan pemberian anggaran dari pemerintah untuk pelaksanaan revitalisasi pasar memiliki andil yang cukup penting bagi pasar tersebut dimana pada akhirnya juga akan berkorelasi dengan stabilitas harga komoditi bahan kebutuhan pokok karena dapat menurunkan fluktuasi harga yang terjadi.

Untuk laju perubahan harga, program revitalisasi dapat mengurangi laju perubahan harga pada empat komoditi yaitu daging ayam, daging sapi, telur, dan cabai rawit. Terdapat 3 komoditi yang memiliki kenaikan laju perubahan harga karena adanya revitalisasi pasar yaitu beras, bawang putih, dan cabai merah.

Berdasarkan kesimpulan, untuk menjaga stabilitas harga komoditas dan pelaksananaan revitalisasi/ pembangunan baru pasar rakyat di daerah, maka pelaksanaan program revitalisasi/ pembangunan baru pasar rakyat agar tetap mengikuti peraturan mengenai pembangunan pasar yang memperhatikan kepadatan penduduk daerah Kabupaten/Kota tersebut karena hal ini dapat memengaruhi besar atau kecilnya pasar yang akan dibangun. Selain itu, juga dapat memengaruhi jumlah pedagang dan konsumen di pasar tersebut.

Pemerintah pusat tetap melakukan monitoring dan evaluasi terhadap daerah yang menerima program revitalisasi/pembangunan baru pasar rakyat sehingga tidak akan timbul tindakan yang merugikan yang dilakukan oleh pihak pasar ataupun pemerintah daerah. Pemerintah juga perlu memperhatikan faktor-faktor lain yang mengakibatkan terjadinya fluktuasi harga komoditas seperti jumlah permintaan dari konsumen dan juga jumlah stok/supply dari komoditas.

\section{UCAPAN TERIMA KASIH}

Penulis mengucapkan terima kasih yang sebesar-besarnya kepada pihak Magister Perencanaan Ekonomi dan Kebijakan Publik (MPEKP) Fakultas Ekonomi dan Bisnis Universitas Indonesia, pihak Kementerian Perdagangan, serta reviewer yang sudah membantu. Ucapan terima kasih 
juga penulis sampaikan kepada

Pusbindiklatren Bappenas yang telah mendanai penelitian ini.

\section{DAFTAR PUSTAKA}

Arimbawa, I. G. N. A. A., \& Marhaeni, A. A. I. N. (2017). Analisis Efektivitas Program Revitalisasi Pasar Tradisional di Pasar Desa Adat Intaran Sanur. Jurnal Kependudukan dan Pengembangan Sumber Daya Manusia Universitas Udayana, 13 (1), 18-26.

Ceballos, F., Hernandez, M. A., Minot, N., \& Robles, M. (2017). Grain Price and Volatility Transmission from International to Domestic Markets in Developing Countries. Elsevier World Development Vol. 94, 305-320.

Crucini, M. J., Shintani, M., \& Tsuruga, T. (2010). The Law of One Price without the border: The role of distance versus sticky prices. Economic Journal, 120(544), 462-480.

Direktorat Jendral Perdagangan Dalam Negeri, Kementerian Perdagangan. (2017). Percepatan Revitalisasi Pasar Rakyat. Di Unduh tanggal 14 Oktober 2019 dari http://ditjenpdn.kemendag.go.id/detail lartikel/4/percepatan-revitalisasipasar-rakyat

Gujarati, Damodar N.; Porter, D. C. (2009). Basic Econometrics (Fifth Edit). New York: The McGraw-Hill/Irwin.

Hegerty, S. W. (2016). Commodity-price volatility and macroeconomic spillovers: Evidence from nine emerging markets. North American Journal of Economics and Finance, $35,23-37$.

Irawan, B. (2016). Fluktuasi Harga, Transmisi Harga, dan Marjin Pemasaran Sayuran dan Buah. Analisis Kebijakan Pertanian, 5(4), 358-373.

Ismiyati. (2017). "Standar Revitalisasi Pasa Tradisional Di Indonesia (Studi Kasus
Pasar Tradisional Di Kota Semarang)," Jurnal Karya Teknik Sipil S1 Undip, 2017.

Jensen, H. H., \& Manrique, J. (1998). Demand for food commodities by income groups in Indonesia. Applied Economics, 30(4), 491-501.

Kornher, L., \& Kalkuhl, M. (2013). Food Price Volatility in Developing Countries and its determinants. 53rd annual conference Berlin, German ( $p$. 30). Berlin, German: German Association of Agricultural Economists (GEWISOLA).

Media Indonesia. (1 Agustus 2019). Mahalnya Harga cabai menjadi biang kerok inflasi. Diunduh tanggal 9 Desember 2019 dari https://mediaindonesia.com/read/det ail/250723-mahalnya-harga-cabaijadi-biang-kerok-inflasi

Nugraheni, S. R. (2014). Volatilitas Harga Pangan Utama Indonesia Dan Faktor Yang Memengaruhinya. Bogor: IPB.

Nuraeni, D., Anindita, R., \& Syafrial. (Desember 2015). Analysis of Price Variation and Shallot Market Integration in West Java. Habitat, Vol. 26 No. 3, 163-172.

Nurlaela, I., \& Hariani, D. (2017). Analisis Efektvitas Program Revitalisasi Pasar Tradisional Di Pasar Bulu Kota Semarang. Journal of Public Policy and Management Review, 6(2), 515531.

Peraturan Menteri Perdagangan Republik Indonesia Nomor 56/MDag/Per/9/2014 tentang Perubahan Peraturan Menteri Perdagangan Nomor

70/M- DAG/PER/12/2013 tentang

Pedoman Penataan dan Pembinaan Pasar Tradisional, Pusat Perbelanjaan dan Toko Modern

Peraturan Menteri Perdagangan Republik Indonesia Nomor 37/MDag/Per/5/2017 tentang Pedoman Pembangunan dan Pengelolaan Sarana Perdagangan 
Peraturan Menteri Perdagangan RI Nomor 57/M-Dag/Per/8/2017 tentang penetapan Harga Eceran Tertinggi Beras.

Peraturan Menteri Perdagangan RI Nomor 96 Tahun 2018 tentang penetapan Harga Acuan Pembelian di Petani dan Harga Acuan Penjualan di Konsumen

Peraturan Presiden RI No. 71 Tahun 2015 tentang Penetapan dan Penyimpanan Barang Kebutuhan Pokok dan Penting

Peraturan Presiden No.38 tahun 2007 tentang Pembagian Urusan Pemerintahan Antara Pemerintah, Pemerintahan Daerah Provinsi, dan Pemerintahan Daerah Kabupaten/Kota

Pindyck, Robert S., Rubinfeld, D. L. (2013). Microeconomics 8th Edition (8th Edition).

Pusat Informasi Harga Pangan Strategis Nasional, (2019). Informasi Harga Pangan. Diunduh tanggal 9 Agustus 2019 dari

https://hargapangan.id/tabelharga/pasar-tradisional/daerah

Rancangan Awal Rencana Pembangunan Jangka Menengah Nasional 20152019, Buku I, Agenda Pembangunan Nasional.

Ranjani, Ayu S, L., \& Nurhikmah, M. (2018). Implementasi Kebijakan Revitalisasi Pasar Tradisional (studi kasus di BSD Serpong dan Pasar Manis Purwokerto). Jurnal IImu Administrasi Negara, Vol. 9 No. 1, 45-61.
Rizaldy, D. Z. (2017). Pengaruh Harga Komoditas Pangan Terhadap Inflasi Di Kota Malang Tahun 2011-2016. Jurnal Ekonomi Pembangunan, Vol. 15 No. 2, 171-183.

Sharp, P. R., \& Uebele, M. (2013). Rural Infrastructure and Agricultural Market Integration in the United States: A Long Run Perspective. SSRN Electronic Journal.

Sihombing, I. K., Dewi, I. S., \& Al Madany, K. (2019). Analisis Dampak Revitalisasi Pasar Tradisional Terhadap Persepsi Konsumen Dan Pengaruhnya Terhadap Minat Beli Dan Kepuasan Konsumen Di Kota Medan. Jurnal Bis-A: Jurnal Bisnis Administrasi, 8(1), 12-25.

Sihombing, I. K., Dewi, I. S., \& Astika, A. (2019, August). Analisis Kepuasan Konsumen Pada Pasar Tradisional Sebagai Dampak Dari Revitalisasi Pasar Tradisional Di Kota Medan. In Seminar Nasional Sains dan Teknologi Informasi (SENSASI) (Vol. 2, No. 1).

Susanti, S. (2013). Pengaruh produk domestik regional bruto, pengangguran dan indeks pembangunan manusia terhadap kemiskinan di Jawa Barat dengan menggunakan analisis data panel. Jurnal Matematika Integratif, ISSN, 1412-6184. 
